not have been found, for instance, in the outbreak to which Dr. Carter refers. I am, Sirs, yours faithfully, London, June 15th, 1897.

G. S. BUChanaN.

\section{A CASE OF SUDDEN DEATH.}

\section{To the Editors of THE LANOET.}

SIRs,-In Dr. Dixon Mann's interesting article on Urexpected Deaths from Natural Causes he includes gall-stone colic among those diseases which when fatal do not usually end suddenly, but may exceptionally do so. The following case, which came ander my notice in October, 1895, is, I think, of some interest in this connexion. I was called from bed at night to attend a patient whom I had not previously seen, a woman, some fifty-five years of age, living alone in lodgings. She was dead before my arrival, and the people of the house feared that she had died from the effects of poison, self-administered. Their story was briefly as follows. She had complained all day of feeling unwell and had remained in bed secretly solacing herself with brandy. Shortly after twelve o'clock, when the household had retired, she rang her bell furiously, and was found rolling upon the bed in great agony. She complained of severe pain in the abdomen and chest and said: "Give me something to make me sick; if you don't give me something to make me sick I shall die." She repeated these words more than once, was violently sick, and died. A bottle half filled with brandy lay on the bed and several empty bottles were concealed in the room. I took away with me some of the vomited matter and tested for the more common irritant poisons. It contained alcohol in abundance, but I could detect nothing else. By the coroner's order I made a postmortem examination. The gall-bladder was greatly distended by calculi of all sizes to the number of a hundred or more. One of the smaller stones was impacted in the common bile-duct. There was extensive fatty change in the heart muscle. At the inquest a verdict was returned of death from syncope during an attack of biliary colic. I am, Sirs, yours faithfully,

Leicester, June 29th.

T. V. Crosis, M.B. Lond.

\section{"DEATHS AFTER OVARIOTOMY": A COR- RECTION.}

To the Editors of THE LANCET.

SIRS, - My attention has just been drawn to a mistake in $\mathrm{my}$ wording of a footnote (No. 5) on page 1538 of THW LANCET of June 5th. The note in question should read as follows: "The hot water used for this purpose has in every instance been obtained from the usual domestic boilersupply, its temperature being regulated when necessary by the addition of cold water previously sterilised by boiling." I am, Sirs, yours faithfully,

June 28th, 1897. W. A. Meredith.

\section{"SURGERY : ITS REMARKABLE PROGRESS DURING THE REIGN." \\ To the Editors of THE LANCET.}

SIRS,-I beg to call attention to a slight error in your valuable journal of June 19th under the above heading. You state in your article that " the introduction by Leiter of the cystoscope bas greatly facilitated the diagnosis and treatment of diseases of the bladder." The introducer was my late master, Nitze, of Berlin Leiter was only the manufacturer of this instrument. Hoping you will find space for this correction, I am. Sirs, yours faithfully,

Budapest, June 25th, 1897. DR. SAMUEL BAUMgARTEN.

\section{THE LUNACY ACT, 1890, AND ITS AMENDMENTS. \\ To the Editors of THW LANCET.}

SinS, - The principal objects of the Lunacy Act, 1890, were stated in the "Memorandum" to be to furnish safeguards against the improper confinement of persons as lunatics; to remove the difficulty then felt in securing the speedy treatment of mental disease ; to amend the law as to single patients; and to put a check upon the establishment of new licensed houses. A second Amending Bill to the above Act being now before the House of Lords the time seems favour. able for considering how far the objects aimed at in the original Act have been attained during the seven years it has been in operation. On the one hand, complaints are daily heard from asylum officials of the great difficulty they experience in carrying out the numerons, and, as some think unnecessary, provisions of the Act, and of the vastly increased amount of clerical and other labour which it entails; whilst, on the other hand, it is said that the Act. is evaded, that secret, illegal, and irresponsible "treato ment" of the insane, and those threatened with insanity. flourishes and increases. A very influential deputation have just waited upon the Lunacy Commissioners and appear to have spoken strongly and frankly upon the latter facts.

Dr. Blandford, a member of the deputation, is reported to have said: "The intervention of the magistrate presented the greatest difficulty; the friends of the patient make every possible objection to going before the magistrate; and medical men are getting more and more afraid of signing certificates." Dr. Savage said: "At the present moment every person, whether he is a decayed gentleman or a decayed person, thinks he is justified in taking a person of unsound mind into his house, and applications are made hy hundreds and hundreds of them. He believed that if it were known that there was a possibility of the cases being occasionally visited most of those people would not apply to have persons of this kind in their houses." He believed that "the present circumstances tended to secrecy." $\mathrm{Mr}$. Bagot, chairman of the Commissioners, said: "There was another side to this question; he would ask, which is best-for the patient to be treated in a scientific way in an asylum, or casually in a private house?" He drew attention to the legal aspect of the case-Is certification protection against false imprisonment? and thought that all would be agreed that " any feasible plan for putting an end to what must be called the illegal treatment of Junacy was desirable." Dr. Needham, a Commissioner, thought that the strong point of the whole matter existed in the fact that there was a large amount of illicit treatment of insane people going on.

The question seems to arise, under the circumstances here narrated, whether the evils complained of would not be best met, not by further repressive legislation, but by rendering: the whole machinery for reception and treatment into legally and properly constituted asylums, as into other hospitals, as little difficult as possible, a vigilant supervision, of course, being maintained upon all fresh admissions by the medical staff attached to each of them, working loyally and hand in hand with the Commissioners in Lunacy as the supreme authority.

Practically, this state of things already exists, for, under whatever Act a patient is received, once removed from the care of family and friends the medical staffs, supervised by the Lunacy Commissioners, must of necessity assume the full responsibility for any necessary detention. It is hopeless to expect that under any Act, however carefully framed, outcries of illegal detention will not arise from time to time, but such outcries should be at once silenced by the combined testimony of the Commissioners in Lunacy and the medical staffs of the present admirable institutions, both public and private, situated in every county in England.

I am, sirs, your obedient servant,

Formerly a COUNTy Asylum SUPERINTENDENT.

\section{THE RECENT PRIMARY FELLOWSHIP EXAMINATION AT THE ROYAL COLLEGE OF SURGEONS OF ENGLAND. \\ To the Editors of THE LANCET.}

SIRS,-Over 70 per cent. of "plucks"! Over eighty of the most hardworking and intelligent of senior medical students and young practitioners told that they do not know anatomy and physiology in a manner to qualify them for responsible and accurate surgery. This is the outcome of the last primary Fellowship examination at the English College. Something is wrong somewhere. To a plain-thinking surgeon of the old school there appear to be three cardinal faults in the examination. Fault No. 1 -The College has departed from the original scheme of the Fellowship designed by the great leaders in surgical practice and surgical thought of fifty years ago--Brodie, Green, Lawrence, 